\title{
Tourism and Corals in the Bay of Bengal Islands
}

$T^{1}$ he coral reefs of the Bay islands which lie in IndoPacific waters and stretch over $1,962 \mathrm{~km}$ in the Bay of Bengal, harbour about 200 species of corals and comprise a great tourist attraction. North Andaman, North Reef, Ritchie's Archipelago, the Labyrinth group of islands in South Andaman, Little Andaman, Non Cowry, Kamorta, Tillanchang, Little Nicobar, and Great Nicobar, are islands or groups that should be mentioned. The dominant reefbuilding massive corals are species of Favia, Favites, Platygyra, Symphallia, Coniastrea, Diplostrea, and Porites; the branching corals include species of Pacillapora, Stylopora, Seriotopora, Acropora, and Montipora, while the soft corals are species of Helipora, Millepora, Tubipora, Alcynaria, and Gorgonia.

The reefs are of the fringing type, with series of patchreefs along shores, especially in bays and inlets. A $320-\mathrm{km}-$ long barrier reef exists along the west coast of the Andamans, with a 4-m-deep lagoon. Channel reefs are found in Ritchie's Archipelago and South Andaman. Knoll (round hillode of hump-line structure) occurs in channels adjoining the fringing reef of the adjacent islands. In the Andamans the reef-flat extends up to $500 \mathrm{~m}$ from the shore, while in the Nicobars it may do so to $1,000 \mathrm{~m}$.

\section{Multiple Values But Threats}

Coral reefs, apart from their enthralling beauty, act as a buffer zone, provide antibiosis and form an indispensable segment of the local marine ecocomplex, supporting diverse and uniquely rich marine biodiversity involving 'maximum communities'.

The recent decision of the Government of India to encourage tourism in the Andaman and Nicobar Islands, to earn foreign currency and provide employment by utilizing available natural resources, has posed a grave threat to our 'underwater living coral gardens' by accelerating their destruction. The coral-reef flats have already been put under stress by extraction of coral boulders and coastal sands, construction of jetties, siltation due to deforestation, effluents from wood-based industries, and domestic wastes, oil pollution, and activities of shell- and coraltraders. In addition, Crown-of-Thorns Starfish (Acanthaster planci) plaques, recently observed on reefs of the Andamans and Nicobars, have caused considerable loss to the corals. Moreover excessive tourist activities such as trampling, littering, overturning of coral blocks, scuba and snorkel diving, etc., can badly damage the reefs and have already began to leave their most unwelcome marks.

\section{Alarmingly Easy Destruction}

Nature has taken million of years to build up the splendour of underwater 'stone flowers', and the tragic thing is that it can all be destroyed in practically no time by Man. Destruction of coral reefs amounts to extinction of associated faunal elements of coral communities. The Government of India and The Andaman and Nicobar Administration have jointly taken certain measures to protect and conserve the corals. A few of these measures are: Declaration of Wandoor Marine National Park and Sir Huge Rose Island, South Reef Island, and North Reef Island, as sanctuaries, where the Wildlife Protection Act of 1972 has been enforced. But still these measures are not enough to maintain the health, productivity, and biodiversity, of the coral reefs

There is an urgent need to take care of the corals, which could be done through judicious exploitation or total banning of coral collection, zonal management under operational areas, and creating awareness among the local people - especially among those coming into contact with corals - about this vulnerable, fragile, and valuable, marine wealth. Even the slightest delays in necessary action, mismanagement, and carelessness in handling the tourists, could cause eradication of this splendid marine resource from the Bay of Bengal islands.

T.C. KHATRI
J.N. Government College
Port Blair 744104
Andamans
India.

\section{Research Opportunities at Sengwa Wildlife Research Institute, Zimbabwe}

\begin{abstract}
$\mathrm{A}^{\mathrm{n}}$ pplications are invited from established scientists and graduate students interested in conducting research on wildlife/conservation ecology at the Sengwa Wildlife Research Institute, Gokwe, Zimbabwe. The Institute offers visiting researchers comfortable housing and office/ laboratory facilities but they must be responsible for obtaining their own transport and funding.

The Institute is situated in north-west Zimbabwe and is a field station of the Department of National Park and Wild Life Management. It is the headquarters of a $373 \mathrm{~km}^{2}$ conservation area devoted solely to research. The southern boundaries of the field station are fenced to separate wildlife from adjacent subsistence agriculture; the northern boundary is unfenced and adjoins Chirisa Safari Area. Opportunities exist to work in the areas of both the agricultural and wildlife systems.

The vegetation in the research area is diverse, but consists largely of dry deciduous woodlands and shrublands with some riverine grasslands and alluvial woodlands.
\end{abstract}

Animal communities are similarly diverse, and the mammals include 14 ungulate species and Elephants (Loxodonta africana). Check-lists of vertebrate groups and a vegetation map are available upon request.

Preferred subjects of research emphasis include, but are not limited to, the following:

Studies and surveys of biological diversity;

ecosystem/landscape ecology;

ecology of seasonal river systems; and

plant/herbivore interactions.

Institutional partnerships and cooperation with Zimbabwean researchers are encouraged. For further information, contact:

IAN M. Coulson, Senior Ecologist Sengwa Wildlife Research Institute Private Bag 6002 Gokwe Zimbabwe, Southern Africa. 